\title{
Characteristics of equivalent black carbon aerosols over Doon Valley in NW Indian Himalaya during COVID-19 lockdown 2020
}

\author{
Chhavi P. Pandey $\cdot$ Pyar S. Negi
}

Received: 20 August 2021 / Accepted: 17 February 2022 / Published online: 26 February 2022

(C) The Author(s), under exclusive licence to Springer Nature Switzerland AG 2022

\begin{abstract}
Recently, black carbon (BC) has been identified as a potential transmitter for COVID-19 besides being responsible for climate change and serious health hazards. To mitigate the dreaded consequences of COVID-19 pandemic, the Government of India declared a nationwide lockdown on March 24, 2020. Accordingly, observations on equivalent black carbon (EBC) aerosols using AE 51 Aethalometer were performed during different lockdowns in Doon Valley. During April, May, June, and July, the monthly average EBC mass concentration recorded $2.12 \pm 1.14 \mu \mathrm{g} \mathrm{m}^{-3}, 2.58 \pm 1.46 \mu \mathrm{g} \mathrm{m}^{-3}$, $2.74 \pm 1.49 \mu \mathrm{g} \mathrm{m}^{-3}$, and $2.12 \pm 1.32 \mu \mathrm{g} \mathrm{m}^{-3}$, respectively. A comparison of diurnal variation patterns with earlier studies indicates a significant reduction in EBC mass concentration levels. Bipolar NWR analysis for April and May depicts that relatively high EBC concentration was experienced with prominent south-easterly winds. The EBC concentration level during daytime was high compared to nighttime hours. Preliminary visualization of scanning electron micrographs indicates the variable morphology of aerosols. The bulk particle EDX spectral analysis indicates $\mathrm{C}, \mathrm{O}, \mathrm{Na}, \mathrm{F}, \mathrm{Al}, \mathrm{Si}, \mathrm{K}, \mathrm{Ca}$, and $\mathrm{Ti}$ elements with a dominance of $\mathrm{C}$ and $\mathrm{O}$. Windblown dust seems to be the major contributor to the ambient aerosols. Furthermore, MODIS recorded the fire anomaly (attributed to the wheat stubble burning) starting
\end{abstract}

C. P. Pandey $(\bowtie) \cdot$ P. S. Negi

Wadia Institute of Himalayan Geology, 33-GMS Road,

Dehradun, India

e-mail: Chhavi@wihg.res.in from mid of April to early-June along the Indo-Gangetic Basin. Heavy loading of polluted aerosols was visible in CALIPSO data imageries. HYSPLIT cluster trajectories indicate that the study region is strongly influenced by the air mass transporting from the Gangetic Plain, Iran, Pakistan, Afghanistan, and Gulf region.

Keywords Black carbon - COVID-19 lockdown · Air pollution · Himalaya $\cdot$ CALIPSO $\cdot$ MODIS . HYSPLIT

\section{Introduction}

The warming properties of black carbon (BC) are known to accelerate climate change besides being responsible for serious health hazards (U.S. EPA (U.S. Environmental Protection Agency), 2012). However, recently $\mathrm{BC}$ has been identified as a potential agent for rapid transmission of microbes, especially coronavirus that has created health havoc globally during the year 2021 (Rathod \& Beig, 2021). After the suspected emergence of coronavirus (COVID-19) from the Wuhan city in China, it spreads rapidly all over the world. COVID-19 is an infectious viral disease, causing life-threatening acute respiratory syndrome and is capable of rapid human to human infection. Due to its severity and global transmission capability, World Health Organization (WHO) declared the COVID-19 pandemic as an international public health emergency. Initially, social distancing was realized to be the safest 
way of preventing this virus. The government of the Republic of India placed its 1.3 billion citizens under a complete lockdown as a mitigation strategy against COVID-19 and its health hazards. Unprecedented regulations were imposed on the general public to limit the virus spread and to save a life. The lockdown was implemented in four different phases starting from March 24 to May 312020 (Pathakoti et al., 2020). Only emergency services, viz., medical, health care service providers, food supply, and police, were operative, and all the remaining organizations' government/private institutions, industries, factories, school/ colleges/educational institutes, entertainment sector, etc., were completely closed and most of the population was restricted to stay at home, following the standard rules of social distancing. All kinds of public transport services, viz., international/ domestic airlines, trains, buses, trucks, rickshaws, and autorickshaws, except emergency and essential services, viz., an ambulance, police vehicles, trucks for essential services, and defense, were strictly restricted during lockdown period. This pandemic is considered to be one of the biggest tragic events in known human history. As far as ambient air quality is concerned, it has been revealed through various recent publications (Ambade \& Kurwadkar, 2021; Das et al., 2020; Dasgupta \& Srikanth, 2020; Dhaka et al., 2020; Fu et al., 2020; Goel et al., 2021; Jia \& Evangeliou, 2021; Kumari \& Toshniwal, 2020; Nigam et al., 2021; Sree et al., 2021; Zhang et al., 2020) by different research groups throughout the world that the air quality was drastically been improved due to limited emission of aerosols under restricted anthropogenic activities during lockdown period. BC atmospheric aerosols are short-lived climate forcing agents formed during incomplete combustion of fossil fuel and biomass burning and remain in the atmosphere as a particulate matter (Bachmann, 2009; Bond et al., 2013; Colbeck \& Lazaridis, 2013). BC belongs to the sub-category of particulate matter which is capable of strongly absorbing the tropospheric solar radiation in all wavelength ranges and releasing heat to the atmosphere in the form of infrared waves (Liu et al., 2020). Mainly, $\mathrm{BC}$ aerosols reach the ambient atmosphere by natural ways (viz., wildfire, volcanic eruption) or by anthropogenic activities (viz., crop/open burning, vehicular emission, industrial pollution) (Pandey et al., 2020) and are always co-emitted along with gaseous pollutants (Buseck et al., 2012). Depending on particle morphology, source, and prevailing meteorology, $\mathrm{BC}$ particles can stay in the troposphere for a few days to a few weeks. Either by gravitational setting or wet deposition, these particles are removed from the ambient air (Hidy, 2019). Even during this relatively short lifetime, $\mathrm{BC}$ aerosols are capable to impact various atmospheric processes especially warming, precipitation pattern, and cloud formation in a negative way. (Ramanathan \& Carmichael, 2008; Shrestha et al., 2010). BC particles are also reported to create serious health hazards (Pöschl, 2005; U.S. EPA (U.S. Environmental Protection Agency), 2012; Yang et al., 2021). Recently, aerosols have been identified as a mode of rapid air-borne transmission by the COVID19 virus (Jayaweera et al., 2020).

As mentioned earlier that during the lockdown, phase anthropogenic activities, vehicular emission, and industrial pollutions were at their minimal level. EBC mass concentration was measured during this period along the foothills of Himalaya in Doon Valley. It is worth mentioning that according to the standard terminology used in aerosol science, the term "EBC" (equivalent black carbon) must be used in the case when optical measurement technique is applied for the quantitative description of black carbon and "BC" (black carbon) can preferably be used only for the qualitative (Bond et al., 1999; Lack et al., 2014; Petzold et al., 2013).

In the present study, in situ recordings of EBC mass concentration and meteorological parameters observed during the COVID-19 lockdown period were investigated. Observations were performed in Doon Valley at Dehradun city, India, which has already been listed in past years as one of the most polluted cities in India (Deep et al., 2019). This study site may be considered as the representative for the Himalayan foothills in north-western Indian Himalaya. Apart from optical properties, SEM-EDX (scanning electron microscope coupled with energy-dispersive X-ray) analysis was also performed for the morphological understanding and elemental identification of aerosols. Satellite recordings of fire anomaly from MODIS (MODerate resolution Imaging Spectroradiometer) and CALIPSO (Cloud Aerosol Lidar and Infrared Pathfinder Satellite Observation) data images were also analyzed. To investigate the influence of air parcel pathways towards this region, HYSPLIT (Hybrid Single Particle Lagrangian Integrated Trajectory) cluster trajectory model was utilized. 


\section{Site description and regional meteorology}

During different stages of the COVID-19 lockdown period, EBC measurements were performed in Doon Valley along the Himalayan foothills. The word Doon is of Indian linguistic origin and is used to describe broad longitudinal intermontane depressions in the frontal parts of the Himalaya. Doon basins are circumscribed by the outer Siwalik Hills in the South and the Lesser-Himalaya towards the North (Sinha \& Sinha, 2016). Due to the capacity of these depressions for the storage of fertile sediments and hydrological flow, these valleys provide a suitable environment for human settlements with the developed industrial townships. Dehradun, which is the capital city of the state Uttarakhand, India, is situated in one of the Doon valleys along the Himalayan foothills. Dehradun is located between $29^{\circ} 58^{\circ} \mathrm{N}$ to $31^{\circ} 20^{\circ} \mathrm{N}$ latitude and $77^{\circ} 34^{\circ} \mathrm{E}$ to $78^{\circ} 18^{\circ} \mathrm{E}$ longitude at an average altitude of $640 \mathrm{~m}$ amsl in Doon Valley (Panikkar \& Subramanyan, 1996). The high hills in the eastern and northern sides and Siwaliks in the south, River Song in the east, and river Tons on the west offer a unique and interesting synclinal trough-shaped topographical setting to the city Fig. 1a, b. The observing site is within the campus of Wadia Institute of Himalayan Geology (WIHG), located at GMS road, which is one of the busy roadways in Dehradun City (Fig. 1c).

After the creation of Uttarakhand as a separate state in the year 2000, the capital city Dehradun has emerged as an important business, educational and cultural destination, and wholesale trading center for the entire hill region of the Uttarakhand state. According to the last census in 2011, the resident population of the city has already crossed half a million mark and registered a fast growth rate in past decades. More than a million Indian and foreign tourists visit the city every year in the form of a floating population (Government of Uttarakhand, 2018). With a sensitive and fragile ecosystem, this valley region is facing a serious crisis due to unscrupulous development especially urban growth, rapid industrialization, unplanned development, increased vehicular density, and random encroaching on the land use/land cover of the area (Bhat et al., 2017).

The climatic conditions of any region are directly related to the topographical conditions of that region and vice-versa. The weather/climatic conditions not only influence the physical characteristics but also social, economic, and cultural activities. The climate of Dehradun is temperate; winter months are colder with the maximum and minimum temperatures touching $23.4{ }^{\circ} \mathrm{C}$ and $5.2{ }^{\circ} \mathrm{C}$, respectively. The summer in the valley is in general pleasant, but heat is often intense and summer temperatures can reach up to $44{ }^{\circ} \mathrm{C}$ for a few days. Singh et al. (2013) discussed in detail the rising trend of temperature in Doon Valley in the last few decades. Most of the annual rainfall is received during the monsoon season (June-September), with July and August being the rainiest months of the year. Due to altitude variation, local orography, and the influence of high Mussoorie hills, the rainfall and temperature variations within the city are quite considerable (Piyoosh \& Ghosh, 2016).

\section{Methodology}

EBC and meteorological data

In the present study, EBC observations were performed by microAeth AE-51 aethalometer (Cheng $\&$ Lin, 2013). MicroAeth AE-51 is a real-time, portable, self-contained instrument with a built-in pump, flow control, data storage, and battery. The air sample is collected on Teflon coated glass fiber filter media (T60) which is housed in an easy to replace filter strip. The internal pump is set at $99 \mathrm{ml} / \mathrm{min}$ mass flow meter and stabilized by closed-loop control. This instrument performs real-time analysis by measuring the rate of change in absorption of transmitted light due to the continuous collection of aerosol deposits on the filter. Data recorded at $880 \mathrm{~nm}$ wavelength is interpreted as mass concentration of $\mathrm{EBC}$. The measurement time base is $60 \mathrm{~s}$, measurement resolution is $0.001 \mu \mathrm{g} \mathrm{m}^{-3}$, and measurement precision is $\pm 0.1 \mu \mathrm{g} \mathrm{m}^{-3}$ for $1 \mathrm{~min}$ average and $150 \mathrm{ml} / \mathrm{min}$ flow rate. The recording was started from April 7 till July 30, 2020, and discontinued while charging the instrument.

Furthermore, meteorological parameters, viz, wind direction and wind speed, were acquired using an automatic weather station (AWS) (Campbell scientific) (Kesarwani et al., 2012) located at WIHG, campus. 
Fig. 1 (a) Elevation map indicating the topographical setting of Dehra Doon Valley. Lesser Himalaya towards North, outer Shivalik Hills, and Indo-Gangetic basin towards South. (b) Satellite Image indicating growth of Dehradun city along with inset image pointing the site in southern Asia. (c) Cityscape, where the study site is indicated by a red arrow
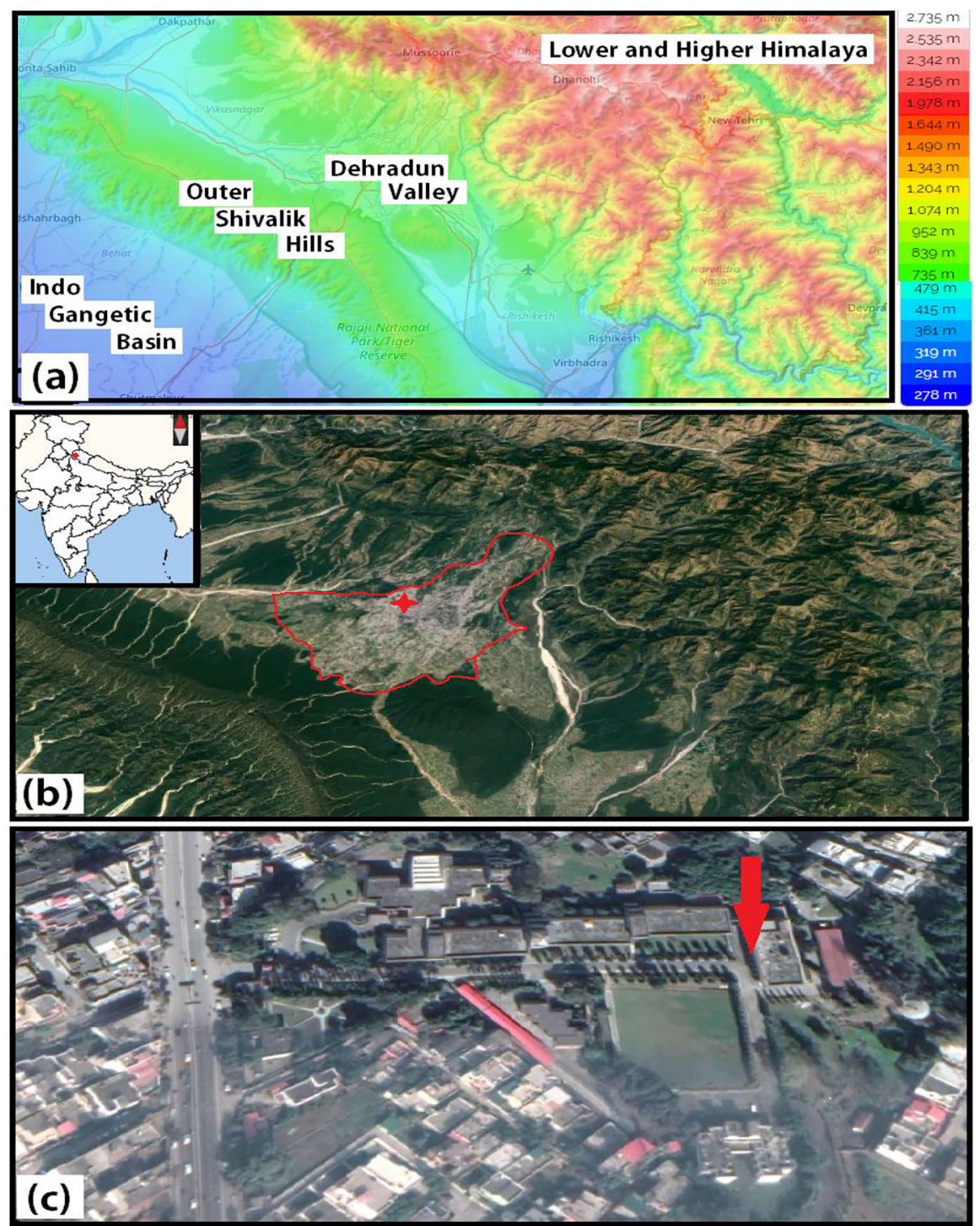

SEM-EDX analysis

To understand morphological and compositional attributes of airborne particles, a scanning electron microscope (SEM-Zeiss EVO-40 EP) coupled with energy dispersive X-ray spectrometer (EDX-Bruker LN2 free X Flash 4010 SDD X-ray detector) facility available at the Central laboratory of Wadia Institute of Himalayan Geology was utilized. The quartz filter strips were coated with gold to prepare the samples for further analysis. Images of the sample were taken at different magnifications. EDX analysis was performed after scanning an electron beam with an accelerating voltage of $15 \mathrm{kV}$ for the determination of bulk particle elemental composition of aerosol particles trapped in the fiber filter.

\section{Cluster analysis}

The Hybrid Single-Particle Lagrangian Integrated Trajectory model (HYSPLIT), developed by NOAA's Air Resources Laboratory, is one of the most widely used models for atmospheric trajectory and dispersion calculations (Stein et al., 2015). HYSPLIT back air trajectory was computed for $500 \mathrm{~m}$ amsl for the study area. Since a large number of trajectories were retrieved, a 
clustering procedure was used to determine representative pathways for the trajectories based on an anglebased distance statistics method.

\section{MODIS}

For the detection of active fire events, satellite observations of fire radiative power (FRP) recorded by Moderate Resolution Imaging SpectroRadiometer (MODIS) instruments, aboard NASA's Terra, and Aqua satellites were used (Kaiser et al., 2012). In the present study, MODIS Collection 6 (C6) active fire product is used for the active fire locations which is the latest version based on the advanced fire detection algorithm and the best available active thermal anomalies product, especially for Himalayan foothill area.

\section{CALIPSO}

The Cloud-Aerosol Lidar with Orthogonal Polarization (CALIOP) instrument on the Cloud-Aerosol Lidar and Infrared Pathfinder Satellite Observations (CALIPSO) spacecraft provide global, high-resolution vertical profiles of aerosols and clouds after it became operational in 2006 (Winker et al., 2009). The CALIPSO satellite data has been used to support the study as it provides new insight into the essential role played by clouds and atmospheric aerosols in regulating Earth's weather, climate, and air quality (Rogers et al., 2011).

\section{Results and discussion}

\section{Diurnal and monthly variation of EBC}

Diurnal variation of surface EBC aerosols during the period of lockdown, i.e., April-July 2020, is shown in Fig. 2. The typical diurnal variations of EBC with prominent two peaks (one in the morning and another in the late evening) as well as a relatively flat pattern during noon is depicted in Fig. 2. During the month of April, the average concentration of EBC starts increasing at about 6:00 IST (Indian Standard Time), attaining its peak nearly around 8:00 IST which starts drastically decreasing between 9:00 to 9:30 IST and reaches its minimum level during 10:00-17:00 IST. Again, the average EBC concentration starts increasing around 17:00 IST, reaches its maximum at 22:00 IST, and finally drops down to a minimum at 23:00
IST. The month of May also depicts a similar pattern. During the months of June and July, the prominent morning and evening peak was not present in the diurnal variation of EBC concentration.

Interestingly, the occurrences of morning peak were observed nearly $1 \mathrm{~h}$ earlier and evening peak was observed nearly one hour advanced in comparison to other progressive months. These critical patterns/ phenomena are directly related to the boundary layer dynamics of EBC aerosols in the region. In general, morning EBC peak occurs mainly due to the combined effect of radiative cooling at the surface, low planetary boundary layer height, and local level of EBC pollutant. During noon hours, boundary layer height increasing (air expands with surface heating by solar radiation intensity) results in proper mixing of pollutants. This expansion of boundary layer and rise in tropospheric temperature allow proper mixing of pollutants which in turn results in a low level of EBC concentration. In general, the peak during the evening hours occurs due to boundary layer dynamics, vehicular rush (in cities), and other increased local anthropogenic activities. But during the period of the present study, i.e., April-May, the region was under complete lockdown state, therefore, hardly any vehicular emission and industrial pollutants contributed to the ambient air composition. Moreover, the monthly mean and standard deviation of EBC mass concentration recorded was $\left(2.12 \pm 1.14 \mu \mathrm{g} \mathrm{m} \mathrm{m}^{-3}\right),\left(2.58 \pm 1.46 \mu \mathrm{g} \mathrm{m} \mathrm{m}^{-3}\right)$, $\left(2.74 \pm 1.49 \mu \mathrm{g} \mathrm{m}^{-3}\right)$, and $\left(2.12 \pm 1.32 \mu \mathrm{g} \mathrm{m}^{-3}\right)$ during April, May, June, and July, respectively.

The diurnal pattern of the EBC mass concentration during this unique situation of lockdown was also compared with earlier studies (during 2011-2017) performed by other authors over the Doon Valley region by using the same optical attenuation technique of data recording as in the present article. Kant et al. (2020) observed that the EBC distribution shows a well-defined diurnal variation with two maxima peaks in the morning and evening hours. Comparing the diurnal variation pattern of the present study shown in Fig. 2, with the earlier study, it is very interesting to observe that the present study follows the same diurnal pattern but less prominent morning peaks and evening peaks with significantly reduced EBS mass concentration levels (Kant et al., 2012, 2015). The reason for this significant reduction is due to the relatively less anthropogenic activities and associated emissions during the complete lockdown 


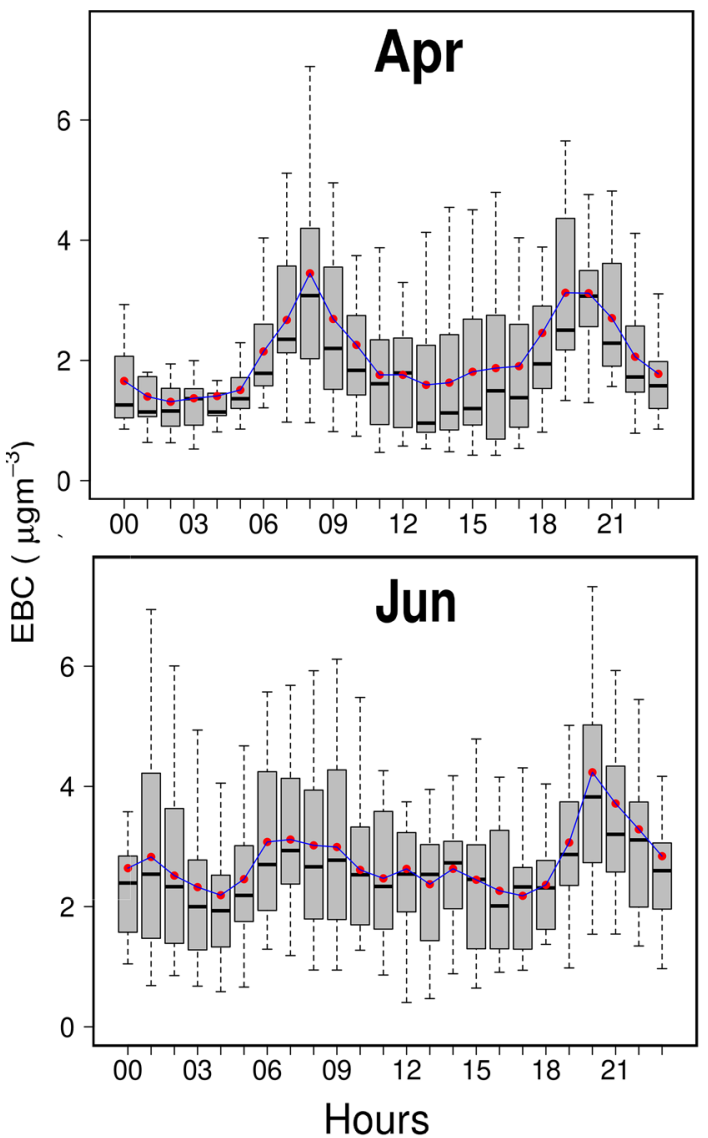

Fig. 2 Diurnal variation box plots of EBC for the months of April, May, June, and July, respectively. The upper and lower boundaries of boxes indicate the 75th and 25th percentiles; the line within the box marks the median; the whiskers above and

period. Furthermore, the relationship of EBC with meteorological parameters and the effect of EBC transport was recently investigated and discussed besides the transport pathways and associated health risks especially respirable suspended particulate matter in Dehradun city (Prabhu et al., 2020; Prabhu \& Shridhar, 2019).

\section{Bipolar NWR analysis}

Wind speed and direction have a paramount influence on the aerosol mass concentration, therefore represent a statistically significant effect on the background levels of air pollutants. Both of these meteorological parameters when simultaneously analyzed with the concentration

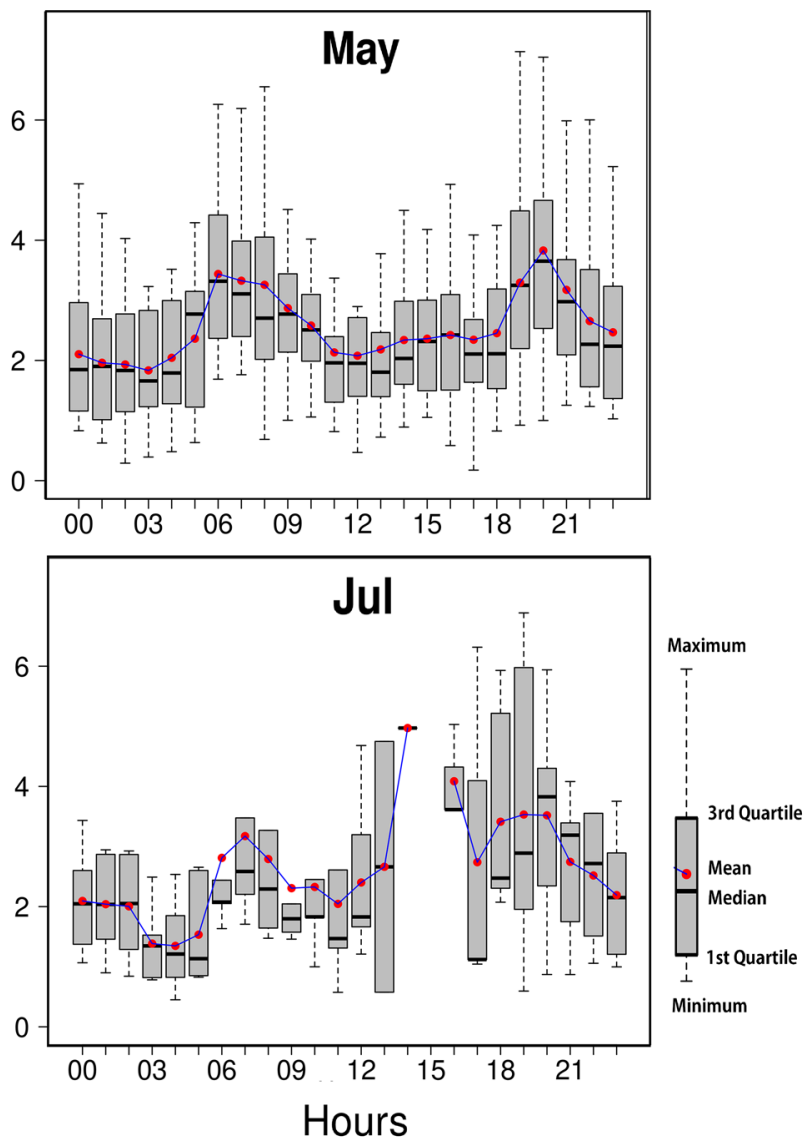

below boxes indicate the maxima and minima respectively; the red dot represent the means; and the blue line is connecting the mean value

of a pollutant species can lead to the identification of source locations and source characteristics (Grange et al., 2016). One of the potential and widespread methods for source characterization of atmospheric pollutants is the bipolar non-parametric wind regression (NWR) analysis (Henry et al., 2002). NWR is a sourceto-receptor source apportionment model that uses nonparametric kernel smoothing methods to apportion the observed average concentration of pollutants (Kim \& Guldmann, 2011). This method can also help in quantifying the effects of local wind direction on background levels of EBC concentration (Carslaw \& Beevers, 2013). Bipolar non-parametric wind regression plots, by calculating the mean EBC concentration for wind speed and direction, are presented in Fig. 3. Figure 3a suggests that 
Fig. 3 Biopolar nonparametric wind regression (NWR) plot of EBC for the months of April and May of complete lockdown period. (a) Bipolar-NWR plots of EBC mass concentration for April and May; (b) bipolarNWR plots for daylight hours (i.e., 06:00-18:00 IST) for April and May; (c) bipolar-NWR plot for night-time hours (i.e., 18:00-06:00 IST) for April and May

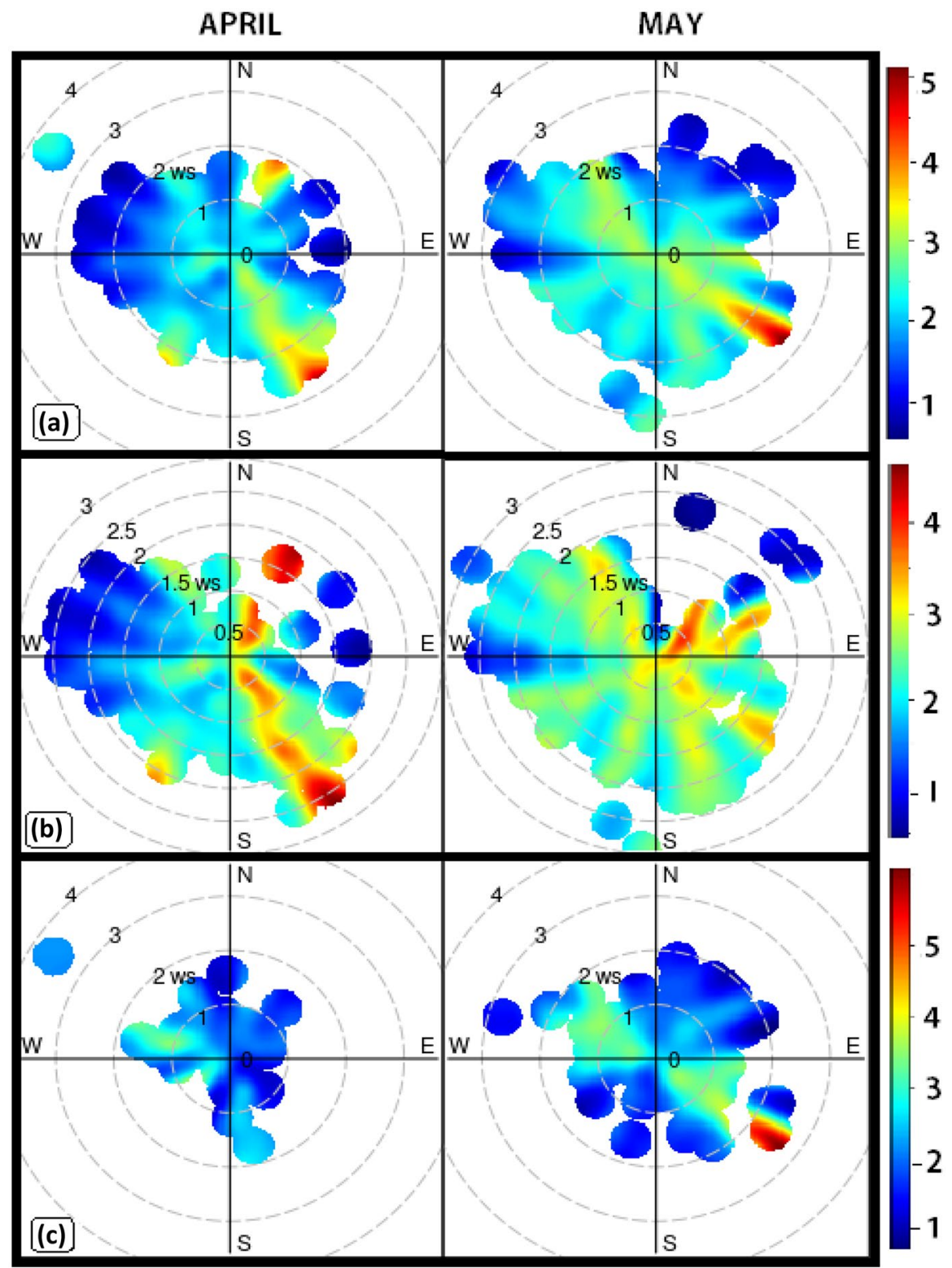

for the months of April and May, locally sourced EBC was present as indicated by the low wind speed. However, a relatively higher concentration was observed with south-easterly winds when wind speed was near $3 \mathrm{~m} / \mathrm{s}$. Figure 3b, c, however, represent bipolar-NWR plots for daylight hours (i.e., 06:00-18:00 IST) and night-time hours (i.e., 18:00-06:00 IST), respectively; daylight and nighttime hours are separated according to sunrise (06:00 IST) and sunset (18:00 IST). After comparison of Fig. 3b with Fig. 3c, we observed that the EBC concentration level during daytime hours was higher than the concerning nighttime hours. Figure $3 \mathrm{c}$ depicts that the concentration level was less in the month of April during night hours, while in the month of May, it was relatively high with the prominent winds in the southeastern direction. During the present computation and visualization of bipolar NWR, R open-source software has been used (Carslaw, 2019). 
Elemental analysis (SEM-EDX)

Morphological observations and compositional analysis for bulk particles were performed using scanning electron micrographs coupled with EDX-spectra. The recording of particulate matter for SEM-EDX analysis was performed from May 17 to 20, 2020. A typical identification map of individual aerosol particles in an electron micrograph is represented in Fig. 4. C, $\mathrm{O}, \mathrm{Na}, \mathrm{F}, \mathrm{Al}, \mathrm{Si}, \mathrm{K}, \mathrm{Ca}$, and Ti elements were identified in that particular micrograph.

The preliminary inspection of scanning micrographs indicates the presence of variable morphological structures like spherical, irregular, layered, aggregated, flaky, and fractal as shown in the sample image (Fig. 5). Many such micrographs were randomly selected for EDX analysis. The EDX spectra infer that the carbon $(\mathrm{C})$ and oxygen $(\mathrm{O})$ content are relatively high with respect to other trace elements viz. ( $\mathrm{C}$ and O) $>90 \%$ and remaining elements are $\mathrm{Si}>\mathrm{Na}>\mathrm{Al}>$ $\mathrm{K}>\mathrm{Ca}>\mathrm{Mg}>\mathrm{Ti}$. It is worth mentioning that a strong peak of Au in the EDX spectrograph (Fig. 5) is due to gold sputter coating over samples. Also, quartz microfiber consists of $\mathrm{SiO}_{2}$; thus, a bulk analysis of aerosol particles may bias the percentage of $\mathrm{Si}$ and $\mathrm{O}$ in the sample.

The high percentage of $\mathrm{C}$ in the ambient air contributed due to the carbonaceous material coming from anthropogenic activities (Srivastava et al., 2009). Although during the lockdown period vehicular emissions were at their minimum; however, other anthropogenic activities, viz, diesel generator and biomass burning, might be the contributor. The group of elements, viz., $\mathrm{Si}, \mathrm{Mg}, \mathrm{Al}, \mathrm{Ca}$, and Ti elements, present in the sample are mainly from windblown dust, re-suspended crustal material, soil dust, construction dust, industrial combustion, biomass burning,

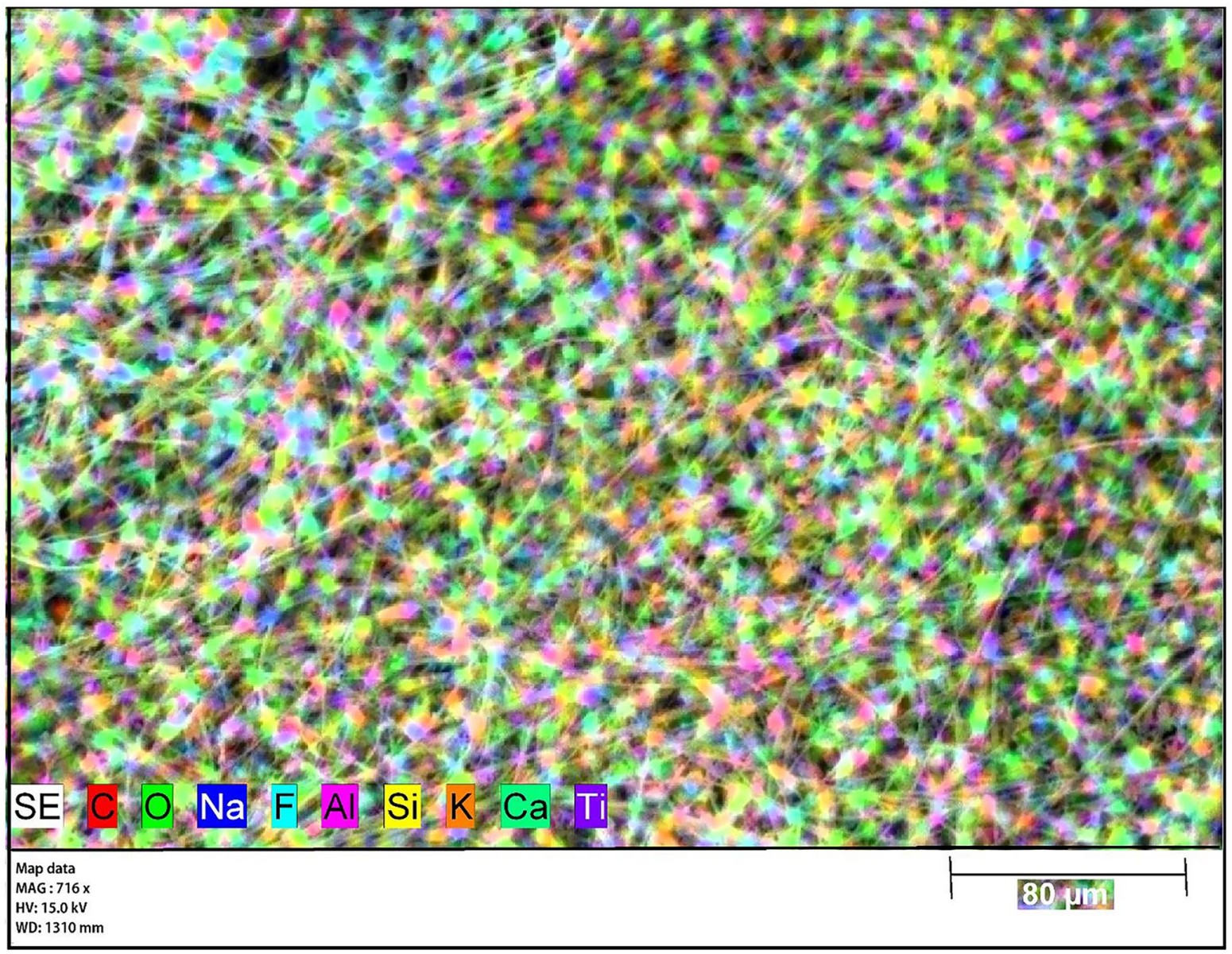

Fig. 4 Identification map of scanning electron micrograph. Different elements are shown in different colors 


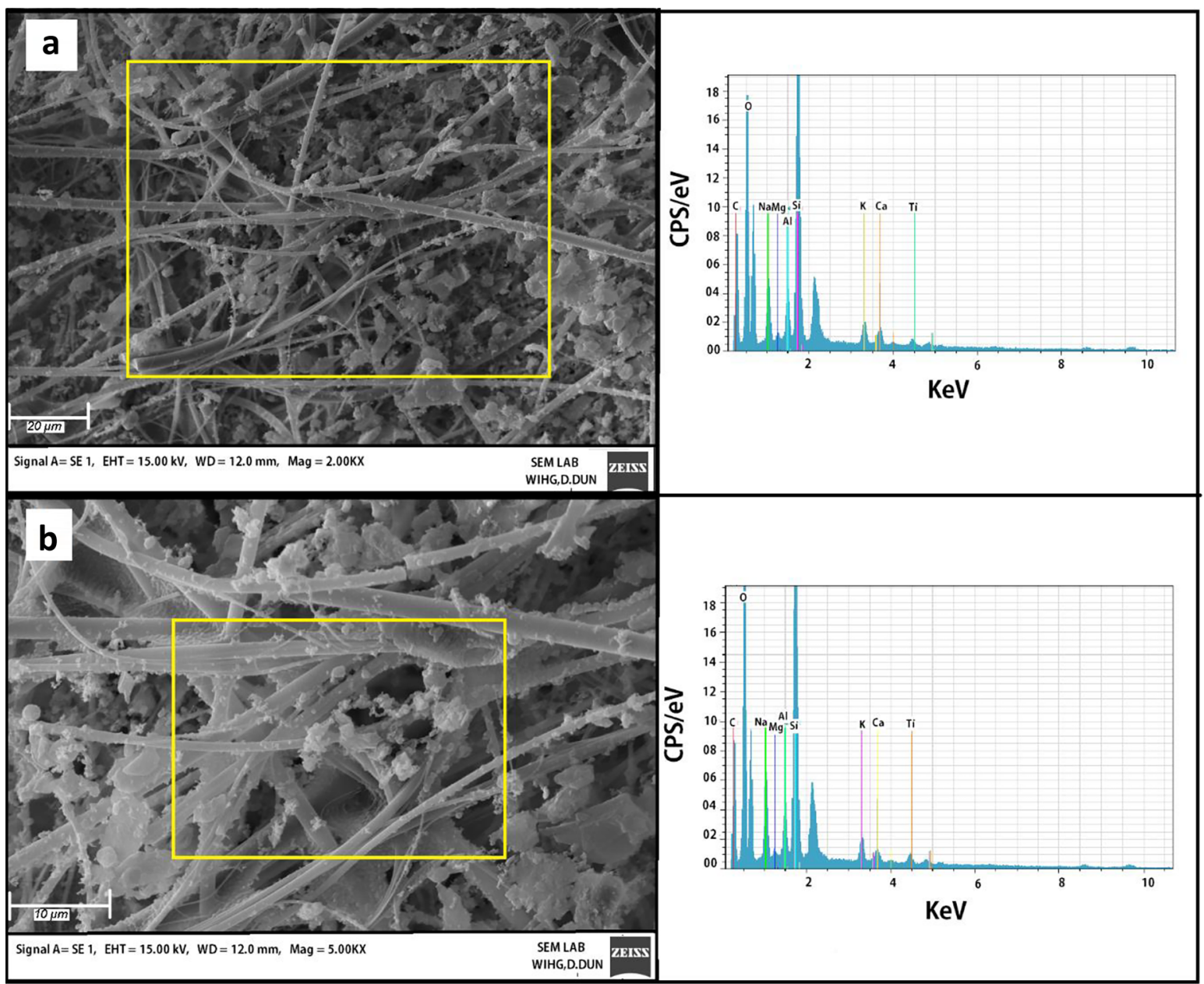

Fig. 5 (a, b) Two examples of a randomly selected unique section of scanning electron micrograph at different resolutions along with the corresponding bulk EDX-spectrum of aerosols at the study site

etc. (Chung et al., 2008; Iordanidis et al., 2008; Jianhua et al., 2006; Pachauri et al., 2013; Sobanska et al., 2000; Srivastava et al., 2009). Soil-derived mineral dust significantly contributes to the global aerosol load (Piazzola et al., 2012) (Jacques Adon et al., 2020). Fine micrometer size windblown soil particles can travel thousands of kilometers through the atmosphere, and dust plumes are predominantly seen in satellite retrievals of global aerosol patterns (Husar et al., 1997).

Fire anomaly, trajectory analysis, and CALIPSO imageries

For the investigation of possible source apportionment, satellite recorded active fire events were also analyzed. Figure 6 represents the active fire anomaly acquired by
MODerate resolution Infrared Spectrometer (MODIS) on-board Aqua and Terra satellites during April-July 2020. In India, the complete lockdown was implemented from March 24 to May 31 in different steps followed by a gradual unlock process in various stages of relaxation. Under essential services, farming activities were permitted in India. Starting from the mid of April, wheat stubble burning incidents were recorded in the north-western agricultural region along the IndoGangetic Basin (Fig. 6).

To elucidate the possibility of local and regional transportation pathways of air parcels towards the study area, cluster analysis using Hybrid Single-Particle Lagrangian Integrated Trajectory (HYSPLIT) analysis was performed for the study period viz. April, May, June, and July (Stein et al., 2015). As depicted in Fig. 7, during the month of 

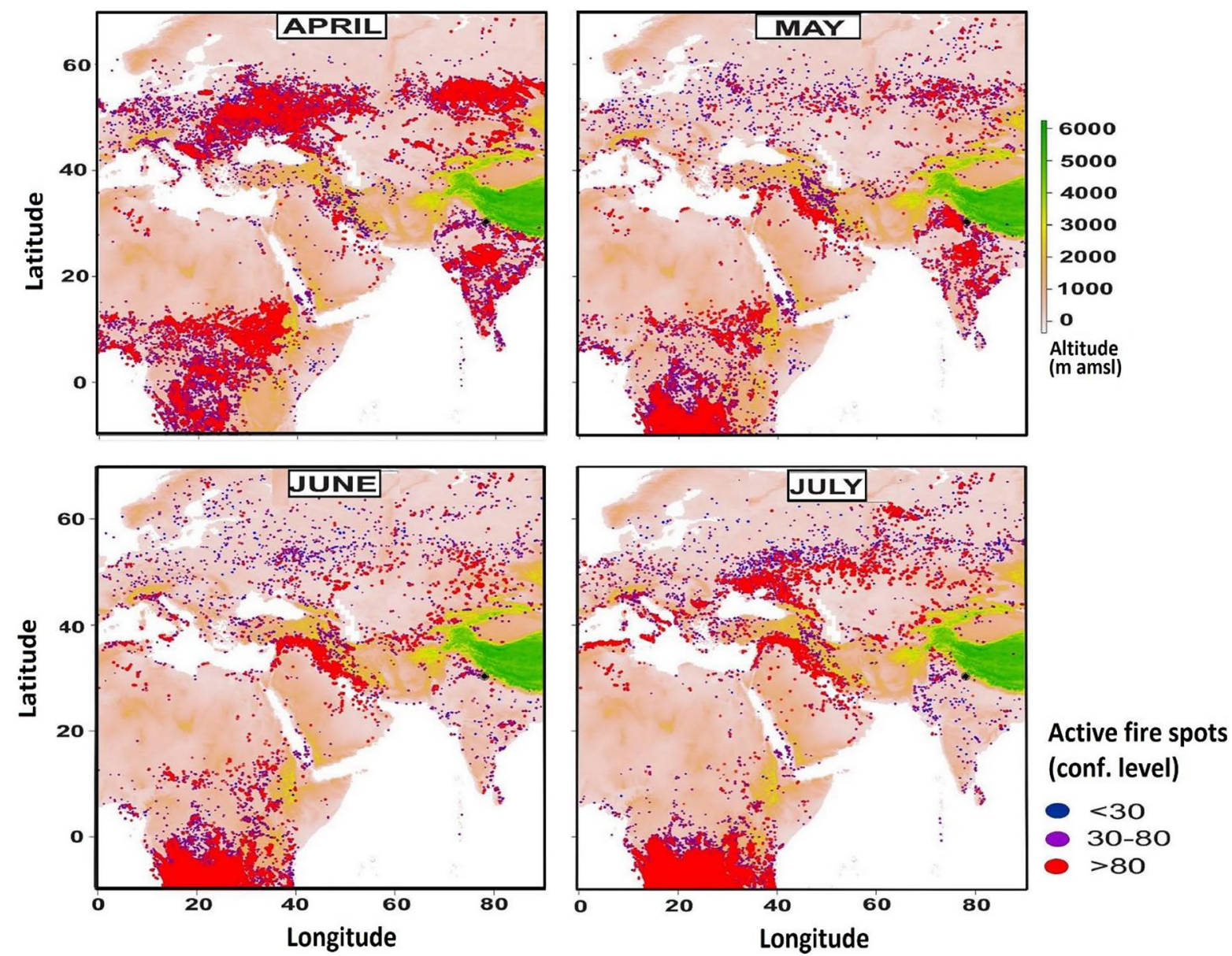

Fig. 6 MODIS detected active fire events (red, purple, and blue dots representing confidence level greater than $80 \%$, between 30 and $80 \%$ and less than $30 \%$, respectively) plotted over elevation map

April, nearly $50-60 \%$ of air mass was transported from the north-western IGP region of India, Pakistan, and Afghanistan and the rest from the gulf region. In the month of May, up to $80 \%$ of the air mass reaching the study area was transported from the pathways including Iran, Afghanistan, Pakistan, and northwestern parts of India. During the month of June, nearly $50 \%$ of air mass reaching towards the study area is from the north-western IGP region, 7.5\% from the eastern region, and 20 to $40 \%$ from long-range travel crossing Pakistan, Afghanistan, and Iran.

In the month of July, the study region was under the influence of monsoonal winds and nearly $50 \%$ of air mass seemed to be transported from the southern part, $40 \%$ was of local origin, and relatively little fraction was coming from the intercontinental distant source.
Furthermore, lidar profiles from CALIPSO spacecraft transiting over the north-western Indian region were analyzed.

Figure $8 \mathrm{a}$ represents the browse image of total attenuated backscatter profiles $\left(\mathrm{km}^{-1} \mathrm{sr}^{-1}\right)$ at $532 \mathrm{~nm}$ transited over the study region on May 17, 2020, 21:02:17.5-21:15:46.2 UTC. Figure 8b depicts the depolarization ratio, Fig. $8 \mathrm{c}$ gives a vertical feature mask, and Fig. 8d denotes the loading of different types of aerosols over the study region. The visual inspection of these imageries provides valuable information regarding the aerosol loading over the region (Giles et al., 2011). The depolarization ratio signifies the degree of particle irregularity (Tian et al., 2020). It has been reported that the depolarization ratio of dust and anthropogenic aerosol ranges from 0 to 0.3 (Sugimoto et al., 2002). In the present study, 


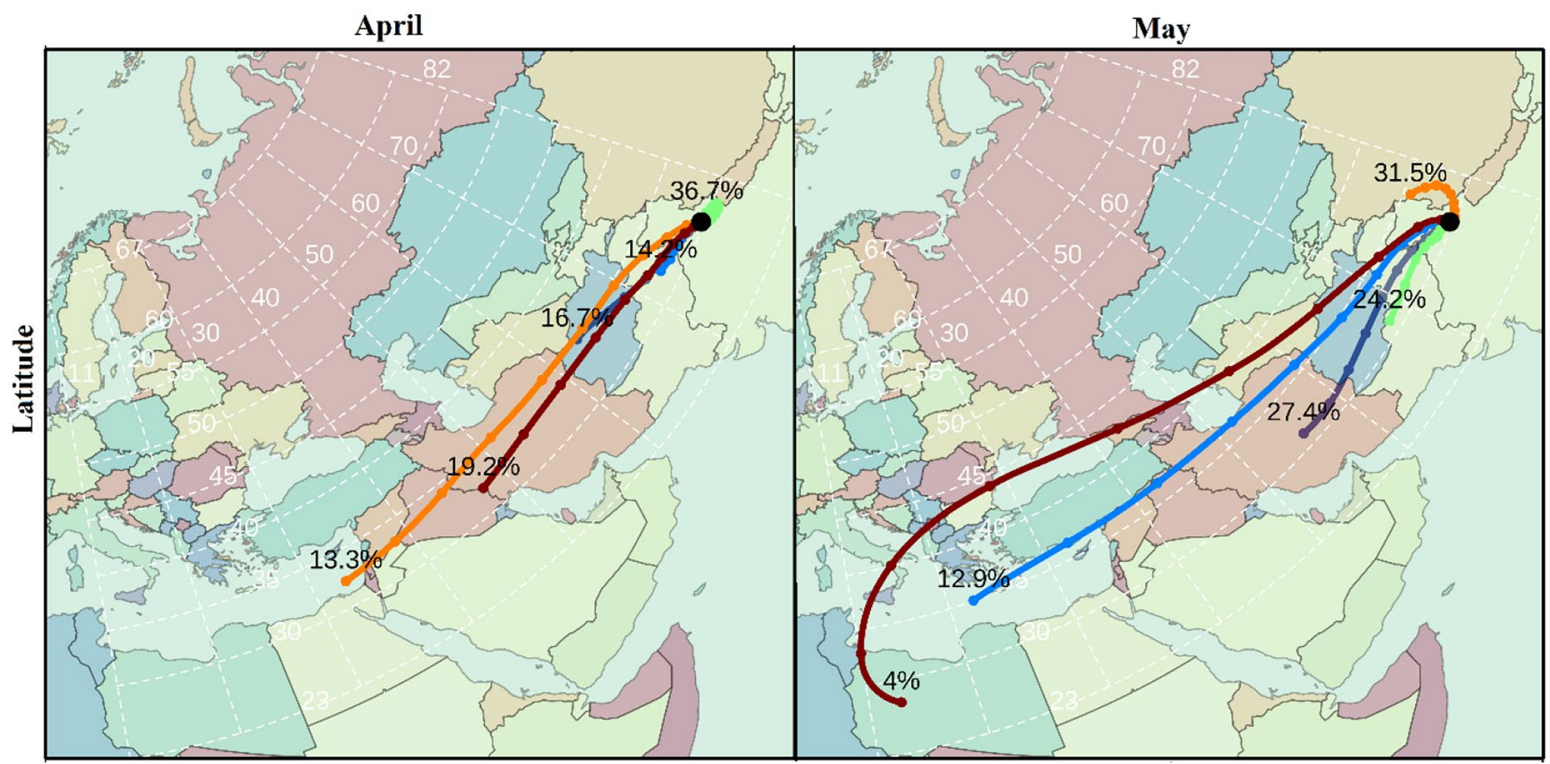

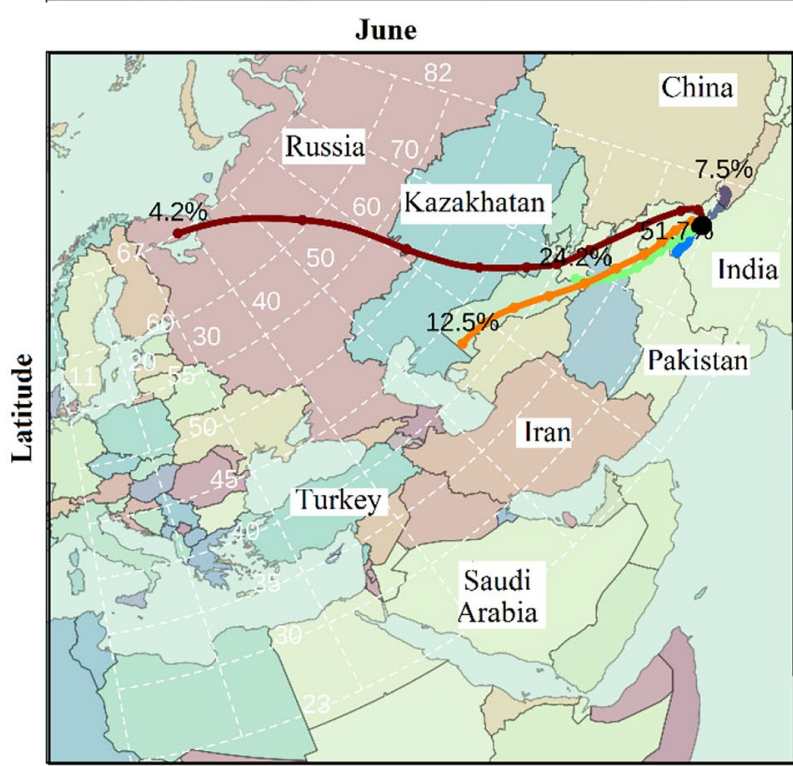

Longitude
July

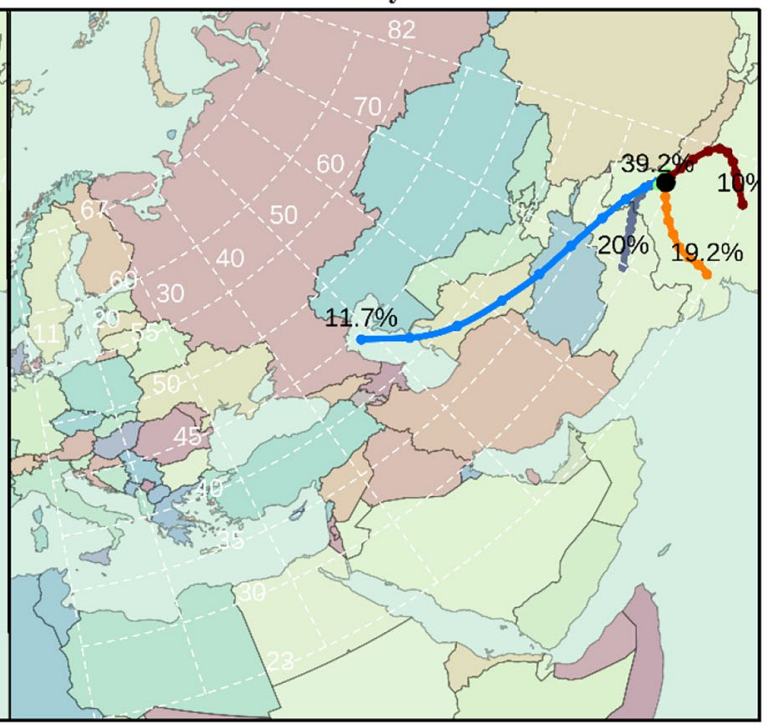

Longitude

Fig. 7 The 4-cluster solutions to monthly resolved HYSPLIT backward trajectories arriving above Dehradun at $500 \mathrm{~m}$ agl, for the months of April, May, June, and July 2020, respectively

it is observed that the depolarization ratio is less than $<0.25$ (Fig. 8b). It signifies that a large number of non-spherical particles dominate the ambient aerosol over the region mainly during the premonsoon season of recording. Figure $8 \mathrm{c}$, d indicate that dust and polluted dust dominate the background aerosol constituent of the region. The complex interaction of Asian dust with anthropogenic pollutants plays a vital role in modifying regional and global climate (Tian et al., 2020). Various uncertainties involved regarding the optical, physicochemical, morphological, and hygroscopic properties of complex aerosol mixture further challenge the accurate estimation of radiative effects (Misra et al., 2014; Schwartz \& Andreae, 1996; Zhuang et al., 2019). Mixed dust plumes with air pollutants may lead to brownish haze having a 
Fig. 8 CALIPSO lidar curtains on 17 May 2020 during 21:02:17.5-21:15:46.2 UTC over north-western Indo-Gangetic Basin in close vicinity of Dehradun valley region. Latitude and longitudes of locations along the CALIPSO ground track are given below the image and altitude $(\mathrm{km})$ is indicated as the vertical axis. (a) $532 \mathrm{~nm}$ attenuated backscatter $\left(\mathrm{km}^{-1} \mathrm{sr}^{-1}\right)$. (b) Depolarization ratio and inset image indicate the satellite track. (c) Vertical feature mask. (d) Loading of different types of aerosols. The white circle indicates the IGB region closely associated with the study site

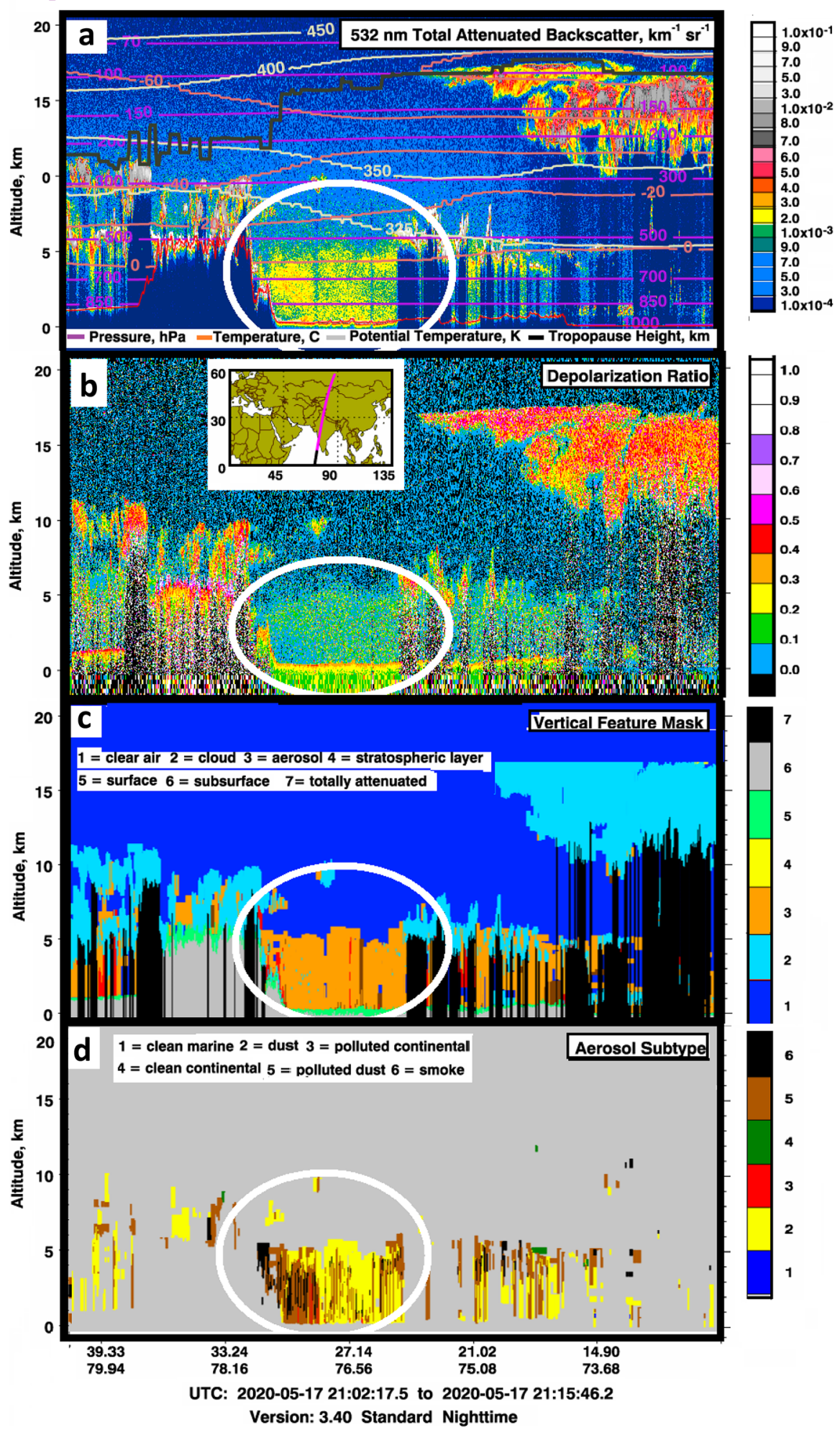


cooling effect by absorbing and scattering solar radiation reaching the surface of the Earth (Kaufman \& Tanré, 2003). However, carbonaceous components attach to the surface of the dust; the mixture of polluted dust can have a strong heating impact on the atmosphere (Seinfeld et al., 2004). Dust particles can also provide reactive surfaces for the gaseous pollutants viz $\mathrm{SO}_{2}$, hence largely increasing the heterogeneous chemical reaction in the atmosphere ( $\mathrm{Li}$ et al., 2016). These contradicting findings emphasize the importance of characterizing the aerosols in diverse contexts as these tiny particles play a huge role in almost all weather and climate phenomena happening in the atmosphere of the Earth (McMurry, 2002; Prather et al., 2008).

\section{Limitations, summary, and concluding remarks}

Characteristics of EBC aerosols during the limited period (April-July 2020) of complete lockdown of 2 months and partial lockdown of next 2 months due to COVID-19 pandemic were analyzed. Observations of EBC mass concentration and meteorological parameters were performed at a clean suburban area of Wadia Institute of Himalayan Geology, a campus located in Doon Valley in north-western Indian Himalaya. SEM-EDX analysis was also performed for morphological visualization and elemental identification. Apart from ground observations MODIS satellite-based fire anomaly and CALIPSO data imageries are also included in the analysis to better understand the aerosol characteristics in the study area. Besides the limitation of not getting a very fine resolution at a particular observing site, CALIPSO images are still an excellent tool to understand the overall loading of aerosols on a regional scale. At present, CALIPSO is the only way to provide the 3D perspective of aerosol distribution in the region, thus contributing to source apportionment analysis. Satellite observations are independent of geographical boundaries which is an important advantage that is not available ( $\mathrm{Li}$ et al., 2009). HYSPLIT air trajectory model is considered to be one of the most extensively used atmospheric transport and dispersion models in the atmospheric science community. Within limitations, this model is capable to provide an essential glance regarding the pollutant transport pathways towards the region of interest.

The main conclusions drawn from the present study are summarized as follows:
1. The monthly mean and standard deviation of EBC mass concentration was $\left(2.12 \pm 1.14 \mu \mathrm{g} \mathrm{m}^{-3}\right)$, $\left(2.58 \pm 1.46 \mu \mathrm{g} \mathrm{m}^{-3}\right),\left(2.74 \pm 1.49 \mu \mathrm{g} \mathrm{m}^{-3}\right)$, and $\left(2.12 \pm 1.32 \mu \mathrm{g} \mathrm{m}^{-3}\right)$ during April, May, June, and July, respectively.

2. Comparison of diurnal variation pattern with previous studies indicates that the present dataset follows the same diurnal pattern but less prominent morning and evening peaks with significantly reduced EBC mass concentration levels which might be due to drastically reduced anthropogenic activities during the study period.

3. Bipolar NWR analysis for the months of April and May depicts that relatively high EBC concentration was experienced with prominent south-easterly winds. It was also realized that the concentration level during daytime hours was relatively high concerning nighttime hours.

4. Preliminary study of scanning electron micrographs indicates variable morphology of aerosols, viz, spherical, irregular, layered, aggregated, flaky, fractal, and grapes-like structures. Bulk particles EDX spectra show the presence of $\mathrm{C}, \mathrm{O}, \mathrm{Na}, \mathrm{F}, \mathrm{Al}, \mathrm{Si}, \mathrm{K}$, $\mathrm{Ca}$, and $\mathrm{Ti}$ elements with a dominance of $\mathrm{C}$ and $\mathrm{O}$. Windblown dust seems to be the major contributor to the $\mathrm{EBC}$ aerosols in the present investigation.

5. Wheat stubble burning incidents starting from mid of April to early-June were recorded by the satellite observations (MODIS). This might be the reason behind the heavy loading of polluted aerosols over the region. The heavy load is also visible in CALIPSO data imageries recorded during the same period.

6. HYSPLIT cluster trajectories indicate that the region of study is strongly influenced by the air mass approaching from the western direction.

Furthermore, the present study opens a possibility for future long-term multi-seasonal optical and physicochemical characterization of aerosol pollutants in the foothill Himalayan region.

Acknowledgements The authors sincerely thank Director, WIHG, for his support and encouragement in carrying out the research work at the institute. The authors would like to thank Mr. N. K. Juyal for his technical support during SEM imaging and EDX analysis. The authors gratefully acknowledge the NOAA Air Resources Laboratory (ARL) for the provision of the HYSPLIT transport and dispersion model and/or READY website (http://www.ready.noaa.gov) used in this publication. 
MODIS and CALIPSO science teams are acknowledged for the provision of satellite data. The R-core team is acknowledged for providing open-source software packages. Thanks is also due to the unknown editor and reviewers for their critical suggestions to improve the quality of manuscript.

Data availability The data that support the findings of this study are available from the corresponding author upon reasonable request.

\section{Declarations}

Conflict of interest The authors declare no competing interests.

\section{References}

Ambade, B., \& Kurwadkar, S. (2021). Emission reduction of black carbon and polycyclic aromatic hydrocarbons during COVID-19 pandemic lockdown.

Bachmann, J. (2009). Black carbon: A science/policy primer. Pew Center on Global Climate Change Black 45.

Bhat, P. A., Shafiq, M., \& Mir, A. A., Ahmed, P. (2017). Urban sprawl and its impact on landuse/land cover dynamics of Dehradun City, India. International Journal of Sustainable Built Environment, 6, 513-521. https://doi.org/10. 1016/j.ijsbe.2017.10.003

Bond, T. C., Anderson, T. L., \& Campbell, D. (1999). Calibration and intercomparison of filter-based measurements of visible light absorption by aerosols. Aerosol Science and Technology, 30, 582-600. https://doi.org/10.1080/027868299304435

Bond, T. C., Doherty, S. J., Fahey, D. W., Forster, P. M., Berntsen, T., Deangelo, B. J., Flanner, M. G., Ghan, S., Kärcher, B., Koch, D., Kinne, S., Kondo, Y., Quinn, P. K., Sarofim, M. C., Schultz, M. G., Schulz, M., Venkataraman, C., Zhang, H., Zhang, S., Zender, C. S. (2013). Bounding the role of black carbon in the climate system: A scientific assessment. Journal of Geophysical Research Atmospheres, 118, 53805552. https://doi.org/10.1002/jgrd.50171

Buseck, P. R., Adachi, K., Gelencsér, A., Tompa, É., \& Pósfai, M. (2012). Are black carbon and soot the same? Atmospheric Chemistry and Physics Discussions, 12, 24821-24846. https://doi.org/10.5194/acpd-12-24821-2012

Carslaw, D. C., \& Beevers, S. D. (2013). Characterising and understanding emission sources using bivariate polar plots and k-means clustering. Environmental Modelling and Software, 40, 325-329. https://doi.org/10.1016/j.envsoft.2012.09.005

Cheng, Y. H., \& Lin, M. H. (2013). Real-time performance of the microaeth ${ }^{\circledR}$ AE51 and the effects of aerosol loading on its measurement results at a traffic site. Aerosol and Air Quality Research, 13, 1853-1863. https://doi.org/10.4209/ aaqr.2012.12.0371

Chung, W., Sharifi, V. N., Swithenbank, J., Ossamor, O., \& Nolan, A. (2008). Characterisation of airborne particulate matter in a city environment. Modern Applied Science, 2. https://doi.org/ 10.5539/mas.v2n4p17

Colbeck, I., \& Lazaridis, M. (2013). Aerosol Science, Aerosol Science. John Wiley \& Sons, Ltd, Chichester, UK. https:// doi.org/10.1002/9781118682555
Das, M., Das, A., Sarkar, R., Saha, S., \& Mandal, A. (2020). Examining the impact of lockdown (due to COVID-19) on ambient aerosols (PM 2.5): A study on Indo-Gangetic Plain (IGP) Cities, India. Stochastic Environmental Research and Risk Assessment 0123456789. https://doi.org/10.1007/s00477-020-01905-x

Dasgupta, P., \& Srikanth, K. (2020). Reduced air pollution during COVID-19: Learnings for sustainability from Indian Cities. Global Transitions, 2, 271-282. https://doi.org/10. 1016/j.glt.2020.10.002

Carslaw, D. (2019). The openair manual 2019.

Deep, A., Pandey, C. P., Nandan, H., Purohit, K. D., Singh, N., Singh, J., Srivastava, A. K., \& Ojha, N. (2019). Evaluation of ambient air quality in Dehradun city during 20112014. Journal of Earth System Science, 128, 1-14. https:// doi.org/10.1007/s12040-019-1092-y

Dhaka, S. K., Chetna, K., Panwar, V., Dimri, A. P., Singh, N., Patra, P. K., Matsumi, Y., Takigawa, M., Nakayama, T., Yamaji, K., Kajino, M., Misra, P., \& Hayashida, S. (2020). PM2.5 diminution and haze events over Delhi during the COVID-19 lockdown period: An interplay between the baseline pollution and meteorology. Scientific Reports, 10, 1-8. https://doi.org/10.1038/s41598-020-70179-8

Fu, F., Purvis-Roberts, K. L., Williams, B. (2020). Impact of the covid-19 pandemic lockdown on air pollution in 20 major cities around the world. Atmosphere, 11. https://doi. org/10.3390/atmos11111189

Giles, D. M., Holben, B. N., Tripathi, S. N., Eck, T. F., Newcomb, W. W., Slutsker, I., Dickerson, R. R., Thompson, A. M., Mattoo, S., Wang, S. H., Singh, R. P., Sinyuk, A., \& Schafer, J. S. (2011). Aerosol properties over the Indo-Gangetic Plain: A mesoscale perspective from the TIGERZ experiment. Journal of Geophysical Research Atmospheres, 116, 1-19. https://doi.org/10.1029/2011JD015809

Goel, V., Hazarika, N., Kumar, M., Singh, V., Thamban, N. M., \& Tripathi, S. N. (2021). Variations in Black Carbon concentration and sources during COVID-19 lockdown in Delhi. Chemosphere, 270, 129435. https://doi.org/10.1016/j.chemosphere. 2020.129435

Government of Uttarakhand. (2018). Human development report of Uttarakhand 1-357.

Grange, S. K., Lewis, A. C., \& Carslaw, D. C. (2016). Source apportionment advances using polar plots of bivariate correlation and regression statistics. Atmospheric Environment, 145, 128-134. https://doi.org/10.1016/j.atmosenv.2016.09.016

Henry, R. C., Chang, Y. S., \& Spiegelman, C. H. (2002). Locating nearby sources of air pollution by nonparametric regression of atmospheric concentrations on wind direction. Atmospheric Environment, 36, 2237-2244. https://doi.org/10.1016/ S1352-2310(02)00164-4

Hidy, G. M. (2019). Atmospheric aerosols: Some highlights and highlighters, 1950 to 2018. Aerosol Science and Engineering, 3, 1-20. https://doi.org/10.1007/s41810-019-00039-0

Husar, R. B., Prospero, J. M., \& Stowe, L. L. (1997). Characterization of tropospheric aerosols over the oceans with the NOAA advanced very high resolution radiometer optical thickness operational product. Journal of Geophysical Research Atmospheres, 102, 16889-16909. https://doi. org/10.1029/96jd04009

Iordanidis, A., Buckman, J., Triantafyllou, A. G., \& Asvesta, A. (2008). ESEM-EDX characterisation of airborne particles from an industrialised area of northern Greece. Environmental 
Geochemistry and Health, 30, 391-405. https://doi.org/10. 1007/s10653-007-9124-y

Jacques Adon, A., Liousse, C., Thierno Doumbia, E., BaezaSquiban, A., Cachier, H., Léon, J. F., Yoboué, V., Barthel Akpo, A., Galy-Lacaux, C., Guinot, B., Zouiten, C., Xu, H., Gardrat, E., \& Keita, S. (2020). Physico-chemical characterization of urban aerosols from specific combustion sources in West Africa at Abidjan in Côte d'Ivoire and Cotonou in Benin in the frame of the DACCIWA program. Atmospheric Chemistry and Physics, 20, 5327-5354. https://doi.org/10. 5194/acp-20-5327-2020

Jayaweera, M., Perera, H., Gunawardana, B., \& Manatunge, J. (2020). Transmission of COVID-19 virus by droplets and aerosols: A critical review on the unresolved dichotomy. Environmental Research, 188, 109819. https://doi.org/10. 1016/j.envres.2020.109819

Jia, M., \& Evangeliou, N. (2021). Black carbon emission reduction due to COVID-19 lockdown in China. Geophysical Research Letters, 1-10. https://doi.org/10.1029/2021GL093243

Jianhua, Q., Xianguo, L., Lijuan, F., \& Manping, Z. (2006). Characterization of dust and non-dust aerosols with SEM/ EDX. Journal of Ocean University of China, 5, 85-90. https://doi.org/10.1007/bf02919381

Kaiser, J. W., Heil, A., Andreae, M. O., Benedetti, A., Chubarova, N., Jones, L., Morcrette, J. J., Razinger, M., Schultz, M. G., Suttie, M., \& Van Der Werf, G. R. (2012). Biomass burning emissions estimated with a global fire assimilation system based on observed fire radiative power. Biogeosciences, 9, 527-554. https://doi.org/10.5194/bg-9-527-2012

Kant, Y., Patel, P., Mishra, A. K., Dumka, U. C., \& Dadhwal, V. K. (2012). Diurnal and seasonal aerosol optical depth and black carbon in the Shiwalik Hills of the North Western Himalayas : A Case Study of the Doon Valley, India. International Journal of Geology, Earth and Environmental Sciences, 2, 173-192.

Kant, Y., Shaik, D. S., Mitra, D., Chandola, H. C., Babu, S. S., \& Chauhan, P. (2020). Black carbon aerosol quantification over north-west Himalayas: Seasonal heterogeneity, source apportionment and radiative forcing. Environmental Pollution, 257, 113446. https://doi.org/10.1016/j.envpol.2019.113446

Kant, Y., Singh, A., Mitra, D., Singh, D., Srikanth, P., Madhusudanacharyulu, A. S., \& Murthy, Y. N. V. K. (2015). Optical and radiative properties of aerosols over two locations in the north-west part of india during premonsoon season. Advances in Meteorology. https://doi.org/10.1155/ 2015/517434

Kaufman, Y. J., \& Tanré, D. (2003). Satellite remote sensing | Aerosol measurements. Encyclopedia of Atmospheric Sciences 1941-1956. https://doi.org/10.1016/b0-12-227090-8/00347-x

Kesarwani, K., Bhambri, R., Mehta, M., Pratap, B., Kumar, A., Karakoti, I., Verma, A., \& Dobhal, D. P. (2012). Meteorological observations at Chorabari and Dokriani glaciers, Garhwal Himalaya. India. Jour. Ind. Geol. Cong, 4, 125-128.

Kim, Y., \& Guldmann, J. M. (2011). Impact of traffic flows and wind directions on air pollution concentrations in Seoul, Korea. Atmospheric Environment, 45, 2803-2810. https:// doi.org/10.1016/j.atmosenv.2011.02.050

Kumari, P., \& Toshniwal, D. (2020). Impact of lockdown on air quality over major cities across the globe during COVID19 pandemic. Urban Climate, 34, 100719. https://doi.org/ 10.1016/j.uclim.2020.100719
Lack, D. A., Moosmüller, H., McMeeking, G. R., Chakrabarty, R. K., \& Baumgardner, D. (2014). Characterizing elemental, equivalent black, and refractory black carbon aerosol particles: A review of techniques, their limitations and uncertainties. Analytical and Bioanalytical Chemistry, 406, 99-122. https://doi.org/10.1007/s00216-013-7402-3

Li, W., Shao, L., Zhang, D., Ro, C. U., Hu, M., Bi, X., Geng, H., Matsuki, A., Niu, H., \& Chen, J. (2016). A review of single aerosol particle studies in the atmosphere of East Asia: Morphology, mixing state, source, and heterogeneous reactions. Journal of Cleaner Production. https://doi. org/10.1016/j.jclepro.2015.04.050

Li, Z., Zhao, X., Kahn, R., Mishchenko, M., Remer, L., Lee, K. H., Wang, M., Laszlo, I., Nakajima, T., \& Maring, H. (2009). Uncertainties in satellite remote sensing of aerosols and impact on monitoring its long-term trend: A review and perspective. Annales Geophysicae, 27, 27552770. https://doi.org/10.5194/angeo-27-2755-2009

Liu, F., Yon, J., Fuentes, A., Lobo, P., Smallwood, G. J., \& Corbin, J. C. (2020). Review of recent literature on the light absorption properties of black carbon: Refractive index, mass absorption cross section, and absorption function. Aerosol Science and Technology, 54, 33-51. https:// doi.org/10.1080/02786826.2019.1676878

McMurry, P. H. (2002). Chapter 17 A review of atmospheric aerosol measurements. Developments in Environmental Science, 1, 443-517. https://doi.org/10.1016/S1474-8177(02) 80020-1

Misra, A., Gaur, A., Bhattu, D., Ghosh, S., Dwivedi, A. K., Dalai, R., Paul, D., Gupta, T., Tare, V., Mishra, S. K., Singh, S., \& Tripathi, S. N. (2014). An overview of the physico-chemical characteristics of dust at Kanpur in the central Indo-Gangetic basin. Atmospheric Environment, 97, 386-396. https://doi.org/10.1016/j.atmosenv.2014.08.043

Nigam, R., Pandya, K., Luis, A. J., Sengupta, R., \& Kotha, M. (2021). Positive effects of COVID-19 lockdown on air quality of industrial cities (Ankleshwar and Vapi) of Western India. Scientific Reports, 11, 1-12. https://doi.org/10. 1038/s41598-021-83393-9

Pachauri, T., Singla, V., Satsangi, A., Lakhani, A., \& Maharaj Kumari, K. (2013). SEM-EDX characterization of individual coarse particles in Agra, India. Aerosol and Air Quality Research, 13, 523-536. https://doi.org/10.4209/aaqr.2012. 04.0095

Pandey, C. P., Singh, J., Soni, V. K., \& Singh, N. (2020). Yearlong first measurements of black carbon in the western Indian Himalaya: Influences of meteorology and fire emissions. Atmospheric Pollution Research. https://doi.org/10. 1016/j.apr.2020.04.015

Panikkar, S. V., \& Subramanyan, V. (1996). A geomorphic evaluation of the landslides around Dehradun and Mussoorie, Uttar Pradesh, India. Geomorphology, 15, 169-181. https:// doi.org/10.1016/0169-555X(95)00121-K

Pathakoti, M., Muppalla, A., Hazra, S., Dangeti, M., Shekhar, R., Jella, S., Mullapudi, S. S., Andugulapati, P., \& Vijayasundaram, U. (2020). An assessment of the impact of a nation-wide lockdown on air pollution - A remote sensing perspective over India. 1-16.

Petzold, A., Ogren, J. A., Fiebig, M., Laj, P., Li, S. M., Baltensperger, U., Holzer-Popp, T., Kinne, S., Pappalardo, G., Sugimoto, N., Wehrli, C., Wiedensohler, A., \& Zhang, X. Y. (2013). 
Recommendations for reporting black carbon measurements. Atmospheric Chemistry and Physics, 13, 8365-8379. https:// doi.org/10.5194/acp-13-8365-2013

Piazzola, J., Sellegri, K., Bourcier, L., Mallet, M., Tedeschi, G., \& Missamou, T. (2012). Physicochemical characteristics of aerosols measured in the spring time in the Mediterranean coastal zone. Atmospheric Environment, 54, 545-556. https://doi.org/10.1016/j.atmosenv.2012.02.057

Piyoosh, A. K., \& Ghosh, S. K. (2016). A comparative assessment of temperature data from different sources for Dehradun, Uttarakhand, India. Journal of Meteorological Research, 30, 1019-1032. https://doi.org/10.1007/s13351-016-6031-0

Pöschl, U. (2005). Atmospheric aerosols: Composition, transformation, climate and health effects. Angewandte Chemie - International Edition, 44, 7520-7540. https://doi.org/10. 1002/anie.200501122

Prabhu, V., \& Shridhar, V. (2019). Investigation of potential sources, transport pathway, and health risks associated with respirable suspended particulate matter in Dehradun city, situated in the foothills of the Himalayas. Atmospheric Pollution Research, 10, 187-196. https://doi.org/10.1016/j. apr.2018.07.009

Prabhu, V., Soni, A., Madhwal, S., Gupta, A., Sundriyal, S., Shridhar, V., Sreekanth, V., \& Mahapatra, P. S. (2020). Black carbon and biomass burning associated high pollution episodes observed at Doon valley in the foothills of the Himalayas. Atmospheric Research, 243, 105001. https://doi.org/10.1016/j.atmosres.2020.105001

Prather, K. A., Hatch, C. D., \& Grassian, V. H. (2008). Analysis of atmospheric aerosols. Annual Review of Analytical Chemistry, 1, 485-514. https://doi.org/10.1146/annurev. anchem.1.031207.113030

Ramanathan, V., \& Carmichael, G. (2008). Global and regional climate changes due to black carbon. Nature Geoscience, 1, 221-227. https://doi.org/10.1038/ngeo156

Rathod, A., \& Beig, G. (2021). Impact of biomass induced black carbon particles in cascading COVID-19. Urban Climate, 38, 100913. https://doi.org/10.1016/j.uclim.2021.100913

Rogers, R. R., Hostetler, C. A., Hair, J. W., Ferrare, R. A., Liu, Z., Obland, M. D., Harper, D. B., Cook, A. L., Powell, K. A., Vaughan, M. A., \& Winker, D. M. (2011). Assessment of the CALIPSO Lidar $532 \mathrm{~nm}$ attenuated backscatter calibration using the NASA LaRC airborne High Spectral Resolution Lidar. Atmospheric Chemistry and Physics, 11, 1295-1311. https://doi.org/10.5194/acp-11-1295-2011

Schwartz, S. E., \& Andreae, M. O. (1996). Uncertainty in climate change caused by aerosols. Science, 272, 1121. https:// doi.org/10.1126/science.272.5265.1121

Seinfeld, J. H., Carmichael, G. R., Arimoto, R., Conant, W. C., Brechtel, F. J., Bates, T. S., Cahill, T. A., Clarke, A. D., Doherty, S. J., Flatau, P. J., Huebert, B. J., Kim, J., Markowicz, K. M., Quinn, P. K., Russell, L. M., Russell, P. B., Shimizu, A., Shinozuka, Y., Song, C. H., \& Zhang, X. Y. (2004). ACE-ASIA: Regional climatic and atmospheric chemical effects of Asian dust and pollution. Bulletin of the American Meteorological Society, 85, 367-380. https://doi.org/10.1175/BAMS-85-3-367

Shrestha, G., Traina, S. J., \& Swanston, C. W. (2010). Black carbon's properties and role in the environment: A comprehensive review. Sustainability, 2, 294-320. https://doi.org/ 10.3390/su2010294
Singh, O., Arya, P., \& Chaudhary, B. S. (2013). On rising temperature trends at Dehradun in Doon valley of Uttarakhand, India. Journal of Earth System Science, 122, 613622. https://doi.org/10.1007/s12040-013-0304-0

Sinha, S., \& Sinha, R. (2016). Geomorphic evolution of Dehra Dun, NW Himalaya: Tectonics and climatic coupling. Geomorphology, 266, 20-32. https://doi.org/10.1016/j.geomorph. 2016.05.002

Sobanska, S., Coeur, C., Pauwels, B., Maenhaut, W., \& Adams, F. (2000). Micro-characterisation of tropospheric aerosols from the Negev Desert, Israel. Journal of Aerosol Science, 31, 299-322. https://doi.org/10.1016/s0021-8502(00)90355-0

Sree, G. S., Venkata, K., Ranjitha, B., Jagan, B., \& Reddy, M. (2021). Partial reduction of air pollution in India during COVID-19 lockdown 42-45. https://doi.org/10.15406/jabb.2021.08.00250

Srivastava, A., Jain, V. K., \& Srivastava, A. (2009). SEM-EDX analysis of various sizes aerosols in Delhi India. Environmental Monitoring and Assessment, 150, 405-416. https:// doi.org/10.1007/s10661-008-0239-0

Stein, A. F., Draxler, R. R., Rolph, G. D., Stunder, B. J. B., Cohen, M. D., \& Ngan, F. (2015). Noaa's hysplit atmospheric transport and dispersion modeling system. Bulletin of the American Meteorological Society, 96, 2059-2077. https://doi.org/10.1175/BAMS-D-14-00110.1

Sugimoto, N., Matsui, I., \& Shimizu, A. et al. (2002). Observation of dust and anthropogenic aerosol plumes in the Northwest Pacific with a two-wavelength polarization lidar on board the research vessel Mirai. Geophysical Research Letters, 29(19), 7-1-7-4.

Tian, Y., Pan, X., Wang, Z., Wang, D., Ge, B., Liu, X., Zhang, Y., Liu, H., Lei, S., Yang, T., Fu, P., Sun, Y., \& Wang, Z. (2020). Transport patterns, size distributions, and depolarization characteristics of dust particles in East Asia in spring 2018. Journal of Geophysical Research: Atmospheres. 125. https:// doi.org/10.1029/2019JD031752

U.S. EPA (U.S. Environmental Protection Agency) (2012). Report to Congress on black carbon. Department of the Interior, Environment, and Related Agencies Appropriations Act, 2010 388. https://doi.org/10.1016/j.icrp.2009.12.007

Winker, D. M., Vaughan, M. A., Omar, A., Hu, Y., Powell, K. A., Liu, Z., Hunt, W. H., \& Young, S. A. (2009). Overview of the CALIPSO mission and CALIOP data processing algorithms. Journal of Atmospheric and Oceanic Technology, 26, 2310-2323. https://doi.org/10.1175/2009JTECHA1281.1

Yang, J., Sakhvidi, M. J. Z., de Hoogh, K., Vienneau, D., Siemiatyck, J., Zins, M., \& Jacquemin, B. (2021). Longterm exposure to black carbon and mortality: A 28-year follow-up of the GAZEL cohort. Environment International, 157. https://doi.org/10.1016/j.envint.2021.106805

Zhang, M., Katiyar, A., Zhu, S., Shen, J., Xia, M., Ma, J., Harsha, S., Wang, P., \& Zhang, H. (2020). Impact of reduced anthropogenic emissions during COVID-19 on air quality in India 2017.

Zhuang, B. L., Chen, H. M., Li, S., Wang, T. J., Liu, J., Zhang, L. J., Liu, H. N., Xie, M., Chen, P. L., Li, M. M., \& Zhao, M. (2019). The direct effects of black carbon aerosols from different source sectors in East Asia in summer. Climate Dynamics, 53, 5293-5310. https://doi.org/10.1007/s00382-019-04863-5

Publisher's Note Springer Nature remains neutral with regard to jurisdictional claims in published maps and institutional affiliations. 